\title{
Motivasi Masyarakat Palangka Raya Dalam Pelaksanaan Tradisi Menunggu Kuburan Dalam Tinjauan Hukum Islam
}

\author{
Kusuma W \\ MTs N Palangkaraya \\ kusumaw434@gmail.com
}

\begin{abstract}
This study describe what lies behind the people of Palangkaraya carry out the tradition of waiting for the grave, the procedure of the implementation process waiting grave, awaiting a review of Islamic traditions graves in Palangkaraya. The method in this study the author uses descriptive qualitative approach. Batamat is last in the procession this tradition in which its implementation families prepare and sticky rice. In the execution authors found ethics or behavior that can not be justified performed by people who await the grave is sleeping on top of the grave. Tradition waite these graves can be said urf Saheeh because tradition is intended effort of a weak servant of Allah, to pray for the people who are in the grave so that God's mercy for the deceased, aims In order to maintain the graves to prevent theft and does not result in harm those who carry out the tradition of waiting for the tomb, While the tradition waite these graves can be said urf elements are imperfect caused harm to people waiting tombs, such as the implementation of people waiting grave so sick. Constituted with the intention that does not rely upon Allah.
\end{abstract}

Keywords: Motivation, Tradition, Graves and Islamic law.

\section{A. Pendahuluan}

Adat adalah suatu aturan sosial yang telah ada sejak zaman nenek moyang atau sesuatu yang dikerjakan yang diucapkan secara berulang-ulang sehingga dianggap baik dan diterima oleh akal sehat. Dilihat dari pengertian di atas, jelas terlihat bahwa adat atau tradisi sudah berurat, berakar di dalam masyarakat. Oleh karena itu sebuah adat tidak dapat diubah secara drastis ke dalam adat yang baru, melainkan arah yang bisa terjadi yaitu adat dapat menciptakan sesuatu yang baru baik berupa hukum atau adat yang baru. Akan tetapi, adat dalam kajian di atas hanya secara umum, sedangkan kajian secara keIslaman belum sepenuhnya diketahui. Karena itu, bahwa ajaran

${ }^{1}$ Soerjono Soekanto, Hukum Adat Indonesia, Ed. 1, Cet. 6, ( Jakarta: RajaGrafindo Persada, 2003), hal.137 
Islam adalah ajaran yang fleksibel dan tidak menutup kemungkinan akan adanya lapangan ijtihad. Adapun kajian adat dalam tinjauan Islam yaitu, urf.

Dalam hukum Islam sendiri, sama artinya dengan tradisi atau kebiasaan yang dapat dijadikan suatu hukum. Hal ini didukung dengan salah satu kaidah fiqhiyah.

Kaidah ini menerangkan bahwa suatu tradisi atau adat kebiasaan di suatu daerah dapat dijadikan suatu hukum. Hal ini berarti membolehkan suatu tradisi selama dalam hukumnya tidak ada dalil syara' yang melarang tradisi tersebut, baik itu dari dalil Alqur'an maupun Sunnah. Dalam hal ini, para ahli ushul Fiqih mendefinisikan bahwa adat dan urf itu sama. Hanya saja, ada sedikit perbedaan diataranya yaitu, urf sebagai tindakan atau ucapan dikenal dan dianggap baik serta diterima akal sehat. ${ }^{2}$ Dilihat dari pemahaman tersebut bahwa dikatakan dari pemahaman adat adalah hukum adat hanya dari kalangan yang memakainya, yaitu terbatas pada suatu komunitas atau masyarakat tertentu saja. Sedangkan urf bersifat lebih luas diterima dan lebih banyak diketahui oleh masyarakat. ${ }^{3}$ DR. Abdul Karim Zaidan, menjelaskan bahwa syarat-syarat berlaku suatu tradisi atau kebiasaan suatu masyarakat dapat dijadikan suatu hukum adalah: Tidak ada perbedaan dalam mengamalkannya atau pada umumnya dilakukan oleh manusia yang dinyatakan dalam kaidah fiqhiyyah yang lain, yaitu sesuatu yang dianggap tradisi apabila sudah berlaku atau seringkali dilakukan orangorang. Tradisi menjadi perbandingan untuk mencapai sesuatu yang ingin kita ketahui hukumnya melalui kebiasaan yang ada sebelumnya. Tidak dianggap adat maupun tradisi apabila sesuatu yang dimaksud telah terjadi. Tradisi atau kebiasaan tersebut tidak bertentangan nash atau dalil Alqur'an maupun As-sunnah termasuk syarat yang ditetapkan antara dua

\footnotetext{
${ }^{2}$ Muchlis Usman, Kaidah-kaidah Ushuliyah dan Fiqhiyah, (Jakarta: PT. RajaGrafindo Persada, 1999), hal. 140.

3 Abdul Azis Dahlan (et al.), Ensiklopedi Hukum Islam, (Jakarta: Ichtiar Baru van Hoeve, 1996), hal. 1877.
} 
orang atau lebih yang melaksanakan akad. ${ }^{4}$ Bagi masyarakat yang melaksanakan tradisi ini beranggapan bahwa kematian tidak sekedar keluarnya ruh dari raga, tetapi juga merupakan peristiwa sakral yang menjadi pintu masuk manusia ke alam selanjutnya. Kematian bukanlah akhir dari perjalanan manusia, tetapi awal dari kehidupan yang lain. Sebagai kehidupan yang baru, maka sudah sewajarnya jika mempersiapkan segala keperluan yang dibutuhkan kelak yaitu dengankeimanan dan keyakinan setiap individu. Pemaknaan terhadap kematian seseorang bukan sekedar sakral. Namun juga merupakan peristiwa yang memiliki makna budaya dan sosial. Hal tersebut, terkait erat dengan posisi individu sebagai anggota masyarakat dan sebagai warga kebudayaan tertentu. ${ }^{5}$ Ketika seseorang meninggal dunia, secara budaya dan sosial menimbulkan kekhawatiran dan tentu saja "keguncangan" sementara dalam masyarakat. Keguncangan itu mereka atasi dengan ritual yang berfungsi untuk mengembalikan stabilitas sosial budaya. Prosesi ritual yang dilakukan dari pendampingan seseorang menghadapi kematian sampai dikuburkannya orang yang telah meninggal. ${ }^{6}$ Bagi sebagian orang setelah pemakaman tidak serta merta prosesi menyelenggarakan jenazah selesai. Adakalanya sekitar beberapa lama setelah pembacaan talqin $^{8}$ atau tepatnya setelah para pelayat jenazah beranjak pulang meninggalkan makam. menyisakan keluarga almarhum (jenazah) yang masih bertahan di area pemakaman, sambil membacakan ayat-ayat Alqur'an minimal hanya membacakan surah Yasin sambil duduk tepat disamping kuburan keluarganya. Tidak lama setelah itu, beberapa orang yang ditugaskan

\footnotetext{
${ }^{4}$ Abdul Karim Zaidan, al Wajiz fi Syarhi al Qawaid al Fiqhiyyah fi Asy Syari'ah al Islamiyah, diterjemahkan oleh Muhyiddin Mas Rida dengan judul al Wajiz 100 Kaidah fiqih dalam kehidupan sehari-hari,( Jakarta: Pustaka Al-Kautsar, 2008), cet. I, hal. 134-135

5 Tersedia Http://Uun-Halimah.Blogspot.Com/2008/06/Upacara-Kematian-Pada-MasyarakatBanjar.Html, on line tanggal 7 mei 2009.

6 Tersedia Http://Melayuonline.Comindculturedig/23/01/Upacara-Kematian-MasyarakatBanjar.Html. on line tanggal 8 mei 2009.
} 
oleh keluarga datang untuk melaksanakan tradisi menunggu kuburan yang tepatnya bernama tradisi batunggu kuburan.

Tradisi ini dilaksanakan oleh pihak keluarga dengan meminta beberapa orang yang akan tinggal dikuburan untuk beberapa waktu lamanya, mereka tidak hanya bertugas menjaga tetapi mereka bertugas membacakan ayat-ayat Alqur'an, selama mereka melaksanakan tradisi menunggu kuburan ini. Tradisi tersebut dimulai kira-kira setelah selesai pembacaan Talqin dan para pelayat jenazah mulai meninggalkan kuburan tersebut. Biasanya tradisi ini dilakukan pada siang dan malam hari oleh beberapa orang selama 24 jam, bisa pula selama tiga hari, tujuh hari, bahkan sampai hari ke 40 (empat puluh) hari orang yang meninggal tadi. Pada kenyataannya di Palangka Raya kebanyakan orang-orang lebih sering melaksanakan tradisi menunggu kuburan tersebut selama tiga hari saja. Oleh karena itu, para pembaca tersebut membangun tenda di samping kuburan atau tepat diarea sekitar area kuburan yang akan dijaga.

Pada malam hari mereka menggunakan lampu petromak atau lampu listrik untuk penerangan mereka agar bisa tetap mengaji Alqur'an. Keluarga dan kerabat cukup menyediakan keperluan dan kebutuahan mereka selama menunggu kuburan. Selain menunggu kuburan yang disertai dengan pembacaan Alquran yang pahala bacaannya dihadiahkan bagi jenazah di dalam kubur, konon ada alasan tertentu mengapa kuburan harus dijaga selama waktu tertentu.

Kegiatan menunggu kuburan ini dilaksanakan baik siang maupun malam sampai pada hari ketiga (maniga hari), tujuh hari, bisa juga sampai hari ke empat puluh bahkan sampai hari ke seratus bagi yang meninggal tadi dengan disertai membacakan ayat-ayat Alqur'an sampai khatam Alqur'an (30 juz). 
Namun, ada juga yang mengadakan hanya satu hari dengan disertai membacakan Alqur'an setelah pembacaan talqin sampai menjelang magrib. ${ }^{7}$

Alasan menunggu kubur menurut sebagian besar masyarakat mereka meyakini bahwa setelah tujuh langkah orang yang terakhir yang ikut mengantarkan jenazah ke pemakaman pulang, maka malaikat akan datang dan langsung menanyai ruh di dalam kuburnya, maka atas alasan itulah mereka menunggu kuburan disertai dengan menghadiahi bacakan ayat-ayat Alqur'an dan juga mendoakan supaya mendapatkan kelapangan dalam kuburnya. Selain itu, mereka juga mendoakan kuburan yang ada disekitar kuburan yang mereka jaga.

\section{B. Kajian Pustaka}

Prof. DR. Alfani Daud dalam bukunya bahwa masyarakat Banjar dari aspek sosial bukan dari aspek hokum, beliau meniadakan memasukkan lampiran-lampiran berupa ayat-ayat Alqur'an dan hadis yang digunakan sebagai dasar terlaksananya tradisi menunggu kuburan, yang melatarbelakangi memotivasi masyarakat banjar melaksanakan sebuah tradisi menunggu kuburan ini. selain itu, hal yang mencolok adalah lokasi penelitiannya yang berbeda Alfani Daud meneliti di daerah Banjarmasin meneliti masyarakat Palangka Raya. Dalam penelitian ini, apa yang melatarbelakangi dan memotivasi masyarakat Palangka Raya melaksanakan tradisi menunggu kuburan, bagaimana tata cara prosesi menunggu kuburan dan bagaimana Islam memandang tradisi menunggu kuburan itu sendiri. Dalam penulisan ini digunakan pendekatan kualitatif. Metode kualitatif ini digunakan karena beberapa pertimbangan: Menyesuaikan metode kulitatif lebih mudah apabila berhadapan dengan kenyataan ganda. Metode ini menyajikan secra langsung hakikat hubungan antara peneliti dan responden. metode ini lebih

\footnotetext{
${ }^{7}$ Departemen Pendidikan dan Kebudayaan, 1981, Adat-Istiadat Daerah Kalimantan Selatan, Jakarta: Proyek penelitian dan Pencatatan Kebudayaan Daerah Departemen Pendidikan dan Kebudayaan
} 
peka dan dapat menyesuaikan diri dengan banyak penajaman pengaruh bersama dan terhadap pola-pola dihadapi. ${ }^{8}$

Menurut Suharsimi Arikunto pendekatan merupakan metode atau cara mengadakan penelitian. Seperti halnya penelitian non eksperimen yang dari segi tujuannya akan diperoleh jenis atau tipe yang akan diambil. ${ }^{9}$ Menurut Bogdan dan Taylor yang dikutip oleh Moleong "metode kualitatif adalah sebgai prosedur penelitian yang mengasilkan data deskriptif berupa kata-kata tertulis atau lisan dari orang-orang dan perilaku yang diamati."Sedangkan menurut M. Nasir menyatakan bahwa deskriptif adalah suatu metode dalam meneliti sekelompok manusia, suatu objek bahkan suatu sistem pemikiran ataupun suatu kelas peristiwa pada masa sekarang yang digambarkan secara sistematis, factual dan akurat mengenai fakta-fakta, sifat- sifat antar fenomena yang diselidiki sehingga penulis dapat memahami serta menghayati antara apa yang terjadi dan apa yang diteliti. ${ }^{10}$

Penelitian ini mengunakan pendekatan kualitatif deskriptif, dengan pendekatan ini menghasilkan data deskriftif yaitu berusaha mengerti dan memahami suatu peristiwa dan kaitan-kaitannya terhadap orang-orang biasa dalam studi tertentu. ${ }^{11}$

\section{Metode Penelitian}

Pendekatan yang digunakan penulis dalam penelitian ini adalah kualitatif deskriptif, dengan menggunakan pendekatan kualitatif deskriptif merupakan metode atau cara untuk mengadakan penelitian seperti halnya penelitian non-eksperimen yang dari segi tujuannya akan diperoleh jenis atau

\footnotetext{
${ }^{8}$ Lexy Moleong, Metodologi Penelitiaf Kualitatif, (Bandung: Remaja Rosdakarya, 2004), hal.5

${ }^{9}$ Suharsimi A, Prosedur Penelitian Suatu Pendekatan Praktek, (Jakarta: Renika Cipta, 1993), hal. 20.

${ }^{10}$ M. Nasir, Metode Penelitian, (Jakarta: Graha Indonesia 1998), hal. 63.

${ }^{11}$ Lexy Moleong, Metodologi Penelitian Kualitatif, Surabaya : Angkasa, 2001, hal. 9.
} 
tipe yang diambil. Pendekatan ini akan menghasilkan data deskriptif yaitu berusaha mengerti dan memahami suatu.

\section{Pembahasan}

Hasil penelitian ini menganalisa tadisi menunggu kuburan di kota Palangka Raya yang menurut keyakinan masyarakat yang bersangkutan proses pelaksanaannya, perlengkapan pendukung, serta alasan yang melatarbelakangi atau bisa disebut motivasi masyarakat melatarbelakangi sehingga upacara ini dapat terlaksana. Selain berkenaan dengan upacaranya dan pihak keluarga yang melaksanakan menunggu kuburan tersebut, juga menggali informasi terhadap orang yang menunggu kuburan tersebut dan juga orangorang yang tidak melaksanakan tradisi ini, sehingga diharapkan nantinya datadata yang diperoleh terlihat perbedaannya.

Dalam pelaksanaan tradisi menunggu kuburan adalah dikarenakan tradisi ini telah lama turun-temurun dilaksanakan. Jika tidak dilaksanakan tradisi menunggu kuburan ada kekhawatiran keluarga mereka bahwa menakutkannya alam kubur dengan azab bagi orang-orang yang tidak bisa menjawab pertanyaan. Sebagian masyarakat Palangka raya yang melaksanakan tradisi ini, mereka memiliki khawatiran terhadap keluarga yang telah meninggal dunia, makanya mereka melaksanakan tradisi menunggu kuburan. Setelah dilaksananakan tradisi ini mereka merasa tenang dan juga dikarenakan tradisi ini sudah turun-temurun dari keturunan mereka. Sebagaimana yang dipaparkan responden FS, AD, NR, YS, dan H.M. Tetapi tidak semua responden mengatakan bahwa tradisi menunggu kuburan ini turun- temurun seperti apa yang dialami oleh YS, karena untuk tradisi ini baru pertama mengetahui karena mengikuti tradisi dari isterinya.

Berdasarkan hasil wawancara diatas, dan informasi yang dapat dipercaya tradisi menunggu kuburan memang sesuatu yang tidak wajib itu 
berdasarkan hasil wawancara dengan $H$. Mukhsin selaku pengelola TPU dijalan cilik riwut $\mathrm{km} .2$, mengatakan bahwa

Menunggu kuburan itu hukumnya tidak wajib, hanya saja sebagian masyarakat yang sudah sejak turun-temurun melaksanakan tradisi ini. Hal ini dikarenakan ada rasa khawatiran terhadap keluarga mereka yang meninggal akan mendapat kesulitan di dalam kuburnya. Ada juga yang hanya ingin dijagakan saja, semua itu wujud ikhtiar manusia saja kepada Allah untuk mengampuni dosa-dosa keluarga mereka yang meninggal. Selain itu, ada banyak hal yang mengapa harus ditunggu, salah satu alasannya adalah adanya kekhawatiran kalau sampai dicuri jenazahnya.

Dari keseluruhan argumen yang disampaikan bahwa motivasi masyarakat kota Palangka Raya dalam pelaksanaan tradisi menunggu kuburan disebabkan adanya niat yang bertujuan: menjaga tradisi yang sudah turuntemurun dilaksanakan keluarga mereka. Agar mendo'akan keluarga mereka dimudahkan dan dilapangkan kuburnya serta dihindar dari azab kubur. Agar pada saat dilaksanakan menunggu kuburan tersebut malaikat Munkar dan Nangkir tidak datang selama masih ada orang membacakan Alqur'an dan berada di area kuburan.

Pelaksanaan tradisi menunggu kuburan ini sebelum dilaksanakaan keluarga bertahan sejenak sampai orang yang menunggu kuburan datang, baru dilaksanakan serah terima, dari keluarga kepada orang yang menunggu kuburan. Dalam pelaksanaannya salah satu dari orang yang menuggu kuburan memimpin dan memulai pembacaan ayat-ayat alqur'an, selama tiga hari. Selama tiga hari itu tidak boleh ditinggalkan paling tidak salah seorang mereka menunggu kuburan atau mereka bergantian. Alasan kenapa kuburan tersebut harus ditunggu selama 3 (tiga) hari, karena konon katanya agar malaikat tidak datang karena kata dari berbagai informan maupun subjek mengatakan hal demikian, sebgaiman hadits yang mereka pahami tujuh langkah orang menghantarkan jenazah ke kubur sampai dikuburkannya jenazah, dan para 
pengantar mulai beranjak meninggalkan kubur maka tujuh langkahsetelah meninggalkan, malaikat datang dan langsung menanyakan jasad dalam kuburnya.

Selain itu, ada alasan lain kenapa melaksanakan, mereka juga berpatok pada sebuah hadits yang menyatakan nabi pernah melewati kuburan dan kemudian menancapkan pelepah kurma yang dibelah beliau seraya berkata semoga daun kurma ini tidak mengering kubur jenazah dalam kubur tersebut diringankan dalam kuburnya.

Selama mereka menunggu kuburan mereka melakukan aktivitas di kuburan, baik itu tidur maupun makan, sedangkan untuk ibadah sholat, mereka akan bergantian. Mereka tidak melaksanakan sholat di lokasi kuburan melainkan sholat ditempat lain, baik itu dimesjid ataupun di lokasi lain yang di anggap tidak ada kuburan di bawahnya, sebagaimana berdasarkan pengamatan penulis ketika observasi di TPU Cilik Riwut. Setelah selesai mereka mendapat imbalan dari keluarga, menurut H.R pemberian imbalan itu semata-mata hadiah bagi orang-orang yang menunggu kuburan disebabkan mereka sudah mau menunggukan kuburan dan menghadiahkan bacaan alqur'an untuk almarhum keluarga mereka.

Selanjutnya, setelah selesai melaksanakan menunggu kuburan dan pembacaan ayat-ayat alqur'an selama tiga hari, maka akan dilaksanakan acara batamat (khatmul) Alqur'an, Batamat atau khatamul Alqur'an ini merupakan prosesi terakhir dalam pelaksanaan tradisi menunggu kuburan dikarenakan sudah menyelesaikan ketiga puluh Juz (bagian) Alqur'an hal ini dirayakan. Acara batamat ini dipimpin oleh salah satu dari tiga orang yang menunggu kuburan, dengan memulai pembacaan surat Fatihah, dan diiringi oleh semua hadirin yang datang yaitu pihak kelurga yang pada saat itu ikut dalam acara batamat. Kemudian bersama-sama membaca QS. 93 (Ad-Dhuha) sampai akhir QS. 115 (An-Naas). Apabila pembacaan surat- surat tersebut selesai, 
upacara dilanjutkan dengan pembacaan zikir tertentu oleh pemimpin acara betamat dan kemudian diakhiri dengan pembacaan do'a khatamul qur'an yang dibaca sering tertera dalam lembaran belakang setiap alqur'an yang beredar di Indonesia.

Acara betamat (Khatmul Qur'an) sering ditemukan dua syarat pokok yang tidak bisa ditinggalkan yaitu: Piduduk dan lakatan (nasi ketan), menurut para subjek hal ini perlu disediakan dalam setiap acara batamat, karena kedua itu syarat yang tidak boleh ketinggalan. Piduduk adalah berupa makanan yang terdiri dari beras biasa ataupun beras ketan secukupnya, telur ayam sebutir, gula merah atau gula pasir secukupnya, kelapa yang sudah dibuang sabutnya, garam, teh dan lain-lain. Pada dasarnya piduduk mempunyai fungsi macam-macam dalam setiap acara adat, tetapi dalam tradisi menuggu kuburan yang dilanjutkan khatmul Qur'an, Piduduk berfungsi sebagai syarat hadiah bagi orang yang menunggu kuburan tapi piduduk ini bisa diganti dengan Uang. Isi piduduk: beras melambangkan rezeki, kelapa melambangkan lemak (kehidupan), gula merah atau gula pasir lambang manis (kehidupan), garam lambang asin (kehidupan), ayam lambang pantang menyerah, telur ayam lambang sum-sum, pisau makna semangat yang keras, lilin lambang penerangan, uang lambang persediaan dalam hidup, jarum dan benang lambang ikatan suami isteri. Selanjutnya seluruh isi yang memimpin acara Khatmul Qur'an. Sedangkan lakatan (nasi ketan) sebagai simbol bahwa ilmu yang didapat atau syafaat membaca Alqur'an dapat melekat seperti nasi ketan setelah memakan nasi ketan yang dimakan.

\section{Tinjauan Hukum Islam Tentang Tradisi Menunggu Kuburan.} Hukum menguburkan jenazah adalah fardhu kifayah, dan hal itu disepakati para ulama. Sedangkan hal-hal lain setelah menguburkan masih dalam perbincangan dan perdebatan para ulama dalam menentukan hukumnya seperti hal tradisi menunggu kuburan. Motivasi Masyrakat Palangka Raya dalam 
Pelaksanaan Tradisi Menunggu Kuburan. Berdasarkan dari berbagai argumen yang disampaikan oleh subjek, berkenaan dengan motivasi mereka melaksanakan tradisi tersebut adalah adanya budaya yang sudah turun temurun dan sebagai wujud ikhtiar kepada Allah agar diampuni dosanya, dilapangkan kuburnya dan dimudahkan dalam menjawab pertayaaan para malaikat saat di kubur. Melihat permasalahan di atas apabila selaku hamba Allah memohonkan dan berusaha dengan jalan ikhtiar berdasarkan pemahaman yang mereka anggap tidak akan bertentangan dengan agama karena ketakutan dan kekhawatiran tentang nasib keluarga mereka yang meninggal. Sebagaimana hadits nabi.

Artinya: Dari Abu hurairah r.a berkata: Rasulullah bersabda: jika anak adam meninggal terputuslah amalnya kecuali dari tiga perkara: Sedekah jariah, ilmu yang bermanfaat atau anak shaleh yang mendoakannya (HR. Muslim) ${ }^{12}$

Tata Cara Pelaksanaan Menunggu Kuburan. Tidak ada dalil secara khusus membolehkan menunggu kuburan, oleh sebab itu ada sebagian ulama yang menyatakan bahwa segala sesuatu yang tidak pernah dikerjakan Nabi Muhammad SAW. adalah bid'ah ${ }^{13}$ dan tidak diragukan lagi bahwa setiap bid'ah dalam agama adalah sesat. menunjukkan bahwa perkara baru yang dibuat-buat dalam Islam itu adalah bid'ah dan bid'ah itu sesat dan tertolak. Rasulullah SAW. sendiri yang mengatakan amalan bid'ah itu tertolak karena tidak terpenuhinya salah satu syarat dari dua syarat diterimanya ibadah, yaitu mutaaba'ah (mengikuti contoh Rasulullah). Syarat diterimanya ibadah ada dua, pertama niat dan ikhlas karena Allah, kedua sesuai dengan sunnah yakni sesuai dengan Alqur'an dan Sunnahnya, jika salah satunya

12 An-Nawawy, Imam Abu Zakaria Yahya bin Syarf, Terjemah Riadhus Shalihin,terjemahan Salim Bahreisj,( Bandung: PT Alma'arif 1986), hal. 271

13 Bid'ah adalah sesuatu yang baru dalam agama setelah agama itu dinyatakan sempurna dan setelah wafatnya Nabi atau sesuatu yang diciptakan namun menyalahi kebenaran yang diterima dari Rasulullah SAW dan prinsip-prinsip agama yang benar. Lihat Syaikh Muhammad'Abdussalam, Bid'ah-Bid'ah yang Dianggap Sunnah, (Jakarta: Qisthi Press, 2005), hal. 34. 
tidak dipenuhi, maka amalnya tersebut tidak bernilai shahih dan tertolak. Abu Yasid dalam bukunya mendefinisikan Bid'ah adalah setiap sesuatu yang ada atau terjadi setelah masa Nabi SAW, baik berupa adat (kebiasaan), ataupun muamalah, baik ataupun jelek. Berdasar pengertian tersebut beliau membagi bid'ah 5 (lima) jenis yaitu Bid'ah wajibah (harus dilakukan), Bid'ah muharramah (tidak boleh diteruskan), bid'ah mandubah (lebih baik ditinggalkan) bid'ah makrumah (sebaiknya tidak dilakukan) dan bid'ah mubahah (boleh saja dilakukan atau ditinggalkan). ${ }^{14}$ Berdasarkan hasil wawancara maupun observasi yang dilaksanakan penulis dalam mengamati pelaksanaan tradisi menunggu kuburan ini, berdasarkan hasil wawancara dengan FS, AD, NR, YS, dan H.M dan informan, pelaksanaan ini dilakukan serah terima. Dimana terdapat akad kalau dibahasakan seperti ini "kami sekeluarga meminta tolong agar kubur keluarga dijaga selama tradisi menunggu kubur”, hal tersebut bertujuan keluarga meminta kepada orang yang menunggu kuburan. Selama melaksanakan menunggu kuburan orangorang yang menunggu membacakan ayat-ayat Alqur'an yang bertujuan pahala bacaannya dihadiahkan buat orang yang meninggal.

Ada beberapa perbedaan pendapat tentang membaca Alqur'an di atas kuburan berkenaan sampainya pahala bacaan Alqur'an kepada jenazah. Sebagaimana pendapat Sayyid Sabiq yang mengutip beberapa pendapat Ulama. Imam Nawawi mengatakan",menerut pendapat yang masyhur dari kalangan syafi'i, pahala membaca Alqur'an tidak sampai kepada jenazah. Imam Ahmad dan sekelompok murid imam syafi'i mengatakan,"Pahala membaca alqur'an sampai kepada mayat. Dan hendaklah setelah membaca alqur'an seseorang berdo'a:"ya Allah, sampaikanlah kepada fulan (pahala) seperti (Al-qur'an) yang hamba baca". Imam Ibnu Qudamah di dalam al-Mugni mengatakan,’Ahmad bi

${ }^{14}$ Abu Yasid, Fiqh Realitas, Yogyakarta: Pustaka Pelajar, 2005, hal. 249-251 
Hambal berkata, Pahala segala kebaikan dapat sampai kepada mayat karena ada nash-nash yang mendukungnya. Disamping itu, kaum muslim disetiap daerah berkumpul untuk membaca alqur'an dan menghadiahkan pahalanya kepada orang-orang yang telah meniggal tanpa ada yang mengingkari. Hal itu merupakan ijma,". ${ }^{15}$ Sayyid sabiq dalam bukunya menjelaskan, orang-orang yang berpendapat bahwa pahala bacaan sampai kepada orang yang sudah meninggal mensyaratkan agar pembaca alqur'an tidak mengambil upah atas bacaanya. Jika ia mengambil upah atas bacaanya, maka pemberian upah itu haram, baik bagi orang yang memberi maupun orang yang diberi, serta pembaca tidak mendapat pahala apapun. Dari pendapat di atas, penulis pahami bahwa jika seseorang melakukan ibadah, seperti membaca Alqur'an dan ia berniat untuk menghadiahkan pahalanya kepada jenazah yang muslim. Maka pahalanya sampai kepada jenazah dan bermanfaat baginya, dengan syarat didahului niat untuk menghadiahkan pahala bukan untuk mendapat imbalan. Sebagaimana di utarakan oleh Ibnu Uqain yang dikutip oleh Sayyid sabiq. Mengenai tentang orang yang menunggu kuburan selama 3 hari tiga malam, Syekh Muhammad arsyad al-Banjari berpendapat: "Makruh bermalam Sendirian di kuburan karena akan menimbulkan rasa takut maka bermalam dikuburan itu mengingatkan kita kepada mati. Ingat akan hancurnya jasad lagi akan menetapkan ingatan kepada Allah maka tidaklah makruh bahkan sunnat". ${ }^{16}$

Jika dalam pelaksanaan ini menimbulkan mudharot bagi orang yang menunggu kuburan, seperti mengakibatkan sakit bagi orang-orang yang menunggu maka hukumnya haram. Hal ini sejalan dengan kaidah fiqih sebagai berikut: Terjemahan: idak boleh membuat madharat pada diri sendiri dan tidak boleh memadharatkan orang lain. Selanjutnya dalam pelaksanaannya

\footnotetext{
${ }^{15}$ Sayyid Sabiq, Fiqih Sunnah, cet. 1,( Jakarta : PT. Pena Pundi Aksara, 2009), hal. 145-146

${ }^{16}$ Syekh Muhammad Arsyad al-Banjari, Kitab Sabilal Muhtadin, (Surabaya: PT. Bina Ilm), hal.180
} 
penulis sering mendapati prilaku orang-orang yang menunggu kuburan tidur disamping kuburan dan ada yang tidur di atas kuburan yang lain. Kaitan tentang prilaku orang yang menunggu kuburan yang tidur di sekitar kuburan masih dalam perbincangan apakah dapat dibenarkan atau tidak dibenarkan sebagaimana hadits nabi sebagai berikut: Terjemahan:"Dan, Zuhair bin Harb menceritakan kepadaku, Jarir menceritakan kepada kami, dari Suhail, dari ayahnya, dari Abu Hurairah radhiyallaahu 'anhu, dia berkata: Rasulullah shallallaahu 'alaihi wa sallam bersabda, "Salah seorang diantara kalian duduk di atas bara api sehingga bajunya terbakar serta sampai melukai kulitnya, maka hal itu masih lebih baik daripada dia duduk di atas makam."(HR. Muslim). Hadits di atas menjelaskan tentang larangan duduk dan sholat di atas kuburan. Mengenai hadits di atas para ulama berbeda pendapat dalam memahami hukum dari hadits di atas yaitu, mazhab Ibnu Hazmin, karena pada hadits tersebut terdapat ancaman. Maka hukumnya haram. Sedangkan Jumhur hanya makruh. berkata imam Nawawi;" melihat gelagat ucapan Syafi'i dalam kitabnya al-Umm, begitupun golongan terbesar megatakan hukumnya makruh duduk di kubur, sebaliknya, ibnu Umar dari golongan sahabat, Abu Hanifah dan Malik menyatakan boleh duduk di kubur. Katanya dalam al-Muwaththa: menurut pendapat -'dugaan' -kami, larangan duduk di atas kubur itu ialah bagi orang yang bermaksud hendak buang air besar atau kecil." 17 Mengenai hadits di atas berdasarkan pemahaman penulis boleh saja, sebagaimana pendapat imam bukhari" diperkenankannya duduk di atasnya dengan tujuan yang dibenarkan, bukan bagi mereka yang hanya berbuat hadats padanya". Beliau menambahkan, "secara lahirnya, yang dimaksud dengan hadats ditempat ini adalah buang air. Namun ada kemungkinan bahwa yang dimaksud itu lebih luas, yaitu melakukan sesuatu yang tidak pantas baik itu berupa perkataan maupun perbuatan yang membuat

\footnotetext{
${ }^{17}$ Sayyid Sabiq, Fiqih Sunnah, jilid 4 hal.110
} 
mayit terganggu." Jadi maksud hadits di atas adalah dengan tujuan sematamata ingin berbuat tidak baik terhadap kuburan orang yang meninggal. Kaitan dengan prilaku orang yang menunggu kuburan yang tidur hadits di atas tidak dapat dijadikan landasan, karena orang-orang yang menunggu kuburan tersebut berniat semata-mata hanya untuk menunggu kuburan, dan dilihat dari kondisi area yang tidak memungkinkan untuk mereka dengan mudah melaksanakan tradisi tersebut sebagaimana kaidah hukum berikut ini: Terjemahan: "Segala sesuatu itu tergantung niat".

Selanjutnya Acara betamat (Khatmul Qur'an) sering ditemukan dua syarat pokok yang tidak bisa ditinggalkan yaitu: Piduduk dan lakatan (nasi ketan), menurut para subjek hal ini perlu disediakan dalam setiap acara batamat, karena kedua itu syarat yang tidak boleh ketinggalan. Piduduk adalah berupa makanan yang terdiri dari beras biasa ataupun beras ketan secukupnya, telur ayam sebutir, gula merah atau gula pasir secukupnya, kelapa yang sudah dibuang sabutnya, garam, teh dan lain-lain. Pada dasarnya piduduk ini merupakan Hindu dalam setiap ritual, tetapi sekarang sudah tergeser dengan budaya Islam sehingga Piduduk dalam prosesi batamat mempunyai fungsi sebagai syarat hadiah bagi orang yang menunggu kuburan tapi piduduk ini bisa diganti dengan uang. Isi piduduk: beras melambangkan rezeki, kelapa melambangkan lemak (kehidupan), gula merah atau gula pasir lambang manis (kehidupan), garam lambang asin (kehidupan), ayam lambang pantang menyerah, telur ayam lambang sum- sum, pisau makna semangat yang keras, lilin lambang penerangan, uang lambang persediaan dalam hidup. Selanjutnya seluruh isi piduduk ini diberikan kepada orang yang memimpin acara Khatmul Qur'an. Sedangkan lakatan (nasi ketan) sebagai simbol bahwa ilmu yang didapat atau syafaat membaca Alqur'an dapat melekat seperti nasi ketan setelah memakan nasi ketan yang dimakan. Dengan demikian dalam prosesi menunggu kuburan sejalan 
dengan jiwa Islam. Oleh sebab itu dapat dipertahankan dan yang tidak sejalan ditinggalkan, agar tidak terjerumus dalam perkara syirik.

\section{E. Kesimpulan}

Dari uraian dan pembahasan yang telah dikemukakan pada bab terdahulu, maka hasil penelitian ini dapat disimpulkan: Motivasi masyarakat Palangkaraya dalam pelaksanaan tradisi menunggu kuburan adalah dikarenakan tradisi ini telah lama turun-temurun dilaksanakan dan merupakan wujud ikhtiar keluarga agar keluarga dimudahkan dan diampuni dosanya serta dilindungi dari azab kubur. Tata cara dan proses pelaksanaanya dimulai setelah pemakaman dan semua yang hadir meninggalkan area kubur, hanya meninggalkan pihak keluarga yang bertahan sampai para penunggu kubur datang, selanjutnya terjadi serah terima. Pada pelaksanaan menunggu kuburan mereka membacakan alqur'an sampai 30 juz selama 3 hari. Pada akhir acara menunggu kuburan diakhiri dengan acara batamat (khatmul qur'an). Batamat merupakan prosesi trakhir dalam tradisi ini. Dalam pandangan hukum Islam tidak ada dalil secara khusus membolehkan tradisi menunggu kuburan. Ditinjau dari hukum Islam Tradisi menunggu kuburan dapat dikategorikan sebagai adat ('urf).'urf dalam pelaksanaan Tradisi menunggu kuburan, terbagi dua macam yaitu 'urf shahih dan'urf fasid.

\section{Daftar Pustaka}

A,Suharsimi, Prosedur Penelitian Suatu Pendekatan Praktek, Jakarta: Renika Cipta, 1993

Al-Banjari, Syekh Muhammad Arsyad, Kitab Sabilal Muhtadin, Surabaya: PT. Bina Ilmu

Abdul Azis Dahlan (et al.), Ensiklopedi Hukum Islam, Jakarta: Ichtiar Baru van Hoeve, 1996.

Abdul Karim Zaidan, al Wajiz fi Syarhi al Qawaid al Fiqhiyyah fi Asy Syari'ah al Islamiyah, diterjemahkan oleh Muhyiddin Mas Rida dengan judul al Wajiz 
100 Kaidah fiqih dalam kehidupan sehari-hari, Jakarta: Pustaka Al- Kautsar, 2008, cet. I.

Daud, Alfani, Islam dan Masyarakat Banjar Deskripsi dan Analisa Kebudayaan Banjar, Jakarta: PT. RajaGrafindo Persada, 1997.

Moleong, Lexy, Metodologi Penelitian Kualitatif, Surabaya : Angkasa, 2001 Muchlis Usman, Kaidah-kaidah Ushuliyah dan Fiqhiyah, Jakarta: PT.

RajaGrafindo Persada, 1999 Nasir, Muhammad, Metode Penelitian, Jakarta: Graha Indonesia 1998

Sayyid Muhammad Al-Muhdhar Bin Alwi Al-Maliki Al-Hasan, Sampaikah Pahala Bacaan Yasin dan Tahlil Kepada Mayyit, Pen. Ahmad Yunus AlMuhdhar, Cet. I, Surabaya: Cahaya Ilmu, 2007

Sayyid Sabiq, Fiqih Sunnah, cet. 1, Jakarta : PT. Pena Pundi Aksara, 2009 Soekanto, Soerjono, Hukum Adat Indonesia, Ed. 1, Cet. 6, Jakarta: RajaGrafindo Persada, 2003.

http://uun-halimah.bl ogspot.com/2008/06/upacara-kematian-pada-masyarakatbanjar.html, on line tanggal 7 mei 2009.

http://melayuonline.comindculturedig/23/01/upacara-kematian-masyarakatbanjar.html. on line tanggal 8 mei 2009 